\title{
FORENSIC EDUCATION: PRACTICAL WAY OF EDUCATING LAW STUDENTS
}

\author{
Muzaffar Syah Mallow \\ Dr., Senior Lecturer,Faculty of Syariah \& Law,Universiti Sains Islam Malaysia (USIM),Bandar Baru \\ Nilai, Negeri Sembilan Darul Khusus, Malaysia, Email: muzaffarsyah.mallow@yahoo.com
}

\begin{abstract}
Educational process is mostly divided into two aspect namely the theoretical aspect as well as practical aspect. Both theoretical and practical aspect of educational process are very important if we want to create a holistic educational environment in the country especially for the students. This matter becoming very crucial in the area of legal education. Students who wishes to pursue their study for legal education should be expose with both area of theoretical and practical aspect of law. Among all the legal subjects offered to be taught to students, the subject on law of evidence can be regarded as the most important subject. This is because in every legal cases whether civil or criminal, the requirement to have evidence is very importance in order to substantiate every allegation put forward by all the disputed parties in the proceeding. The law of evidence, also known as the rules of evidence, encompasses the rules and legal principles that govern the proof of facts in a legal proceeding. The law of evidence is also concerned with the quantum (amount), quality, and type of proof needed in order to prevail in a litigation process. The rules vary depending upon whether the venue is a criminal court, civil court, or family court, and there even vary according to jurisdiction. Law of evidence also set out types of evidence which is admissible and most important the quality of evidence which permitted to be tendered. In order to submit admissible and convincing evidence in supporting cases, it is important to have such evidences to be authenticated properly. This authentication process might involve several process which also includes the calling of an expert from relevant institutions in order to assist the court to derive their final decision over the case. The most widely known institution which can offer such assistance to the court in the country is the Center of Analysis for Forensic Science, Department of Chemistry Malaysia, Ministry of Science, Technology and Innovation (MOSTI), hospitals and various related institutions in the country. For many years, many educational visit has been conducted by almost all law schools in the country to these places in order to expose their students to the practical aspect on law of evidence in particular the forensic matters. However, such educational visit is only be made on voluntarily basis on the initiative taken by the individual lecturer who teach the related subject. The educational visit also normally been conducted in a simple manner and shortest period of time due to the busy schedules faced by both educational institution and the related agencies. Due to this reason, it is the object of this paper to examine in detail over the need to have practical exposure for law students in the area of forensic education and well as proposing an improvement towards the country existing legal education to include practical aspect of forensic education.
\end{abstract}

Keywords: Forensic, evidence, education

\section{INTRODUCTION}

Forensic education is a very important aspect of education for students who are undertaking legal studies not only in Malaysia but across the world. When we talk about forensic education from legal perspective, it is 
very important for us to realize that it's often relates to the process of examination and authentication of piece of evidence submitted to prove court cases. Every piece of evidence tendered must be properly examined and authenticated before the court can accept such evidence to substantiate a case. Due to the advancement of science and technologies, the examination and authentication process of evidence will become much easier, faster, and even credible. The advancement of science and technologies give rise to the area of forensic science. Forensic science is the application of scientific procedures in conjunction with the law. It is important to recognize the role of forensic science especially in the area of criminal prosecution which has proved vital in bringing many criminals to justice who might have otherwise slipped through the net. It is important for us to note that forensic science is not only about investigating the events surrounding and leading of death of any victim, it also be used to prove serious sexual offences cases, grievous bodily assaults, as well as paternity and maternity of a children and family members. Without forensic science many of the crimes which are committed today in our world would go unsolved and it would harder to bring justice to the victim and their family. Forensic science has now become a scientific study in its own right and now includes some of the world's most important discoveries as part of its remit which includes Deoxyribonucleic acid or DNA coding, toxicology (the study of drugs and their effects on the human body), serology (the study of bodily fluids), ballistics (the study of firearms), and many more. (Further reference can be made to Kasinathan Nadesan, 2007, p. 5).

The development area over forensic matters all over the world including in Malaysia also give rise to existence of forensic scientist. Forensic scientists are the one who will collect, preserve, and analyze pieces of evidence which they had received during the course of an investigation. The duty of forensic scientist will become very important, there will be forensic scientist which will travel to the scene of the crime in order to collect the evidence by themselves. There will be also forensic scientist occupy a laboratory role, performing analysis on objects brought to them by authorities or individuals. (Job Description for Forensic Laboratory Scientists. Crime Scene Investigator EDU, 2020). These forensic scientist often been called to the court to deliver their testimony in order to assist the court in giving the final decision. (Further reference can be made to Shahrom Abdul Wahid, 1993, pp: $464-473$ ).

When we talk about forensic education, often it relates to evidence matter. For any legal course which being offered to the legal pupils, law of evidence subject will become the most important legal subject as its embodied the idea over rules of evidence which need to respected and follow by all disputed cases whether in civil or criminal. It is very important for us to examine in detail over this particular subject before moving forward about forensic education itself. The law of evidence or sometimes known as rules of evidence embodied the idea over rules and legal principle which govern proof of facts in a legal proceeding whether in civil cases or criminal cases. (M.R. Zafer, 1994, p. 2). The law of evidence also concerned with the amount or quantum of evidence needed in order to proof cases. Law of evidence govern the admissibility and relevancy of evidence, preventing certain types of bad evidence from being tendered, providing the authentication process of evidence whether in the form of a witness or a document, recognizing certain kinds of privileges, and others. Law of evidence will also ensure every piece of evidence tendered are in good quality, free from doubt and could eventually convince the court to accept such piece of evidence. (Mariette Peters, 2013, pp: 6 -8). There are various standards or quantum's of evidence which must be meet before the court can give its final decision, ranging from reasonable suspicion to preponderance of the evidence or balance of probabilities which often been use in civil cases, as well as clear and convincing evidence, or beyond a reasonable doubt which often been use in criminal cases.

Though the law on evidence might differ from one jurisdiction to another jurisdiction, and it also might differ from court and tribunal, the main objective of a law over evidence is still the same which is to ensure the purity of evidence tendered and to safeguard fairness and justice to all parties in the disputed cases. (A.K. Sarkar and S.K. Awasthi, 1996, pp: 160 -161). Having law over the issue evidence is very crucial in order to avoid any dissatisfaction and disputes among the parties in the future. Having law over the issue of evidence can also make the task of the court much easier in deciding any cases which come to their attention. At the end, having law over the issue of evidence will protect public trust and confidence over the rules of law and judicial system of the country.

In Malaysia, the law of evidence is heavily regulated under the Evidence Act 1950 [Act 56]. Evidence Act 1950 [Act 56] is been regarded as the main source of the law of evidence in the country. Evidence Act 1950 [Act 56] is modeled and based on the Indian Evidence Act of 1872 or identified as Act no. 1 of 1872. This piece of law is mainly based upon the firm work by Sir James Fitzjames Stephen, who could be called the founding father of this comprehensive piece of legislation. Until the existence of the Act, the rules of evidences in India were based on the traditional legal systems of different social groups and communities of India and were different for different people depending on caste, community, faith and social position. The 
existing of Indian Evidence Act introduced a standard set of law applicable to all Indians. When the British started to spread their colonies to other parts of the world by the end of $19^{\mathrm{TH}}$ century including to Singapore and Malaya (Known today as Malaysia), they also bring together with them this legislation to govern the legal system in the country. As a result of these influence, Singapore and Malaya started to create Evidence Ordinances to regulate rules pertaining to evidences for any legal disputes put forward in the court of law. We can say that Malaysian Evidence Act 1950 [Act 56] is being modeled on the Indian Evidence Act which is also consisted many legal elements or legal principles of codified form from the English Law. (Hamid lbrahim and Maimoonah Hamid, 1993, p. 3). It is been pointed out clearly by Thomson CJ (as he then was) in the case of Looi Wooi Saik v PP [1962] MLJ 337, 339 (CA) which stated that "In this country the question is governed by the terms of the Evidence Ordinance which is the same as the Indian Evidence Act...It is generally accepted that the Indian Act was drafted by Sir James Stephen in 1872 with the intention of stating in a codified form of English law relating to evidence as it stood at that date". The Indian Evidence Act which also is based on the English law of evidence in the late $19^{\mathrm{TH}}$ century has been subjected with certain modifications, which were made to suit the local circumstances in India. Similarly goes to the Malaysian Evidence Act 1950 [Act 56]. As result of these certain modification, the Malaysian Evidence Act 1950 [Act 56] has certain provisions which are not found in the Indian Evidence Act of 1872. Important for us to know also that the Evidence Act 1950 [Act 56] applicable to both criminal and civil cases. (Habibah Omar, Siva Barathi Marimuthu, and Mazlina Mahali, 2015, p. 6). Reference can also be made to the case of Saminathan $v$ PP [1955] MLJ 121, PP $\vee$ Yuvuraj [1969] 2 MLJ 89 as well as Re Loh Kah Kheng (1990) 2 MLJ 126 on this regard. (Augustine Paul, 2000, pp. 1 -26).

\section{FORENSIC ASPECTS HIGHLIGHTED UNDER THE EVIDENCE ACT 1950 [ACT 56]}

As mentioned above the main statute which governed the rules of evidence in the country is Evidence Act 1950 [Act 56]. Every pieces of evidence tendered must fulfill the requirement provided under this particular Act. There are various kinds of evidence which can be used to support at a case and be subjected to forensic process. It is thus vital for us to look over the definition of evidence itself as provided under Section 3 of the Act. Section 3 of Evidence Act 1950 [Act 56], the word evidence being defined as "Evidence includes: (a) all statements which the court permits or requires to be made before it by witnesses in relation to matters of fact under inquiry: such statements are called oral evidence; (b) all documents produced for the inspection of the court: such documents are called documentary evidence". The point which can be refer by us is over the word "includes" which being used in this particular section. The use of the word "includes" in this particular section and definition is intended to make the definition of evidence an extensive one. This means that the meaning of the word evidence in the section goes beyond the narrow statutory meaning explicitly set out. Evidence does not confine to oral testimony or documentary evidence only, it can include other things as well like physical evidence, real evidence, direct evidence, circumstantial evidence and others. (Further reference can be made to Hamid Sultan Abu Backer, 2014, pp: 78 - 104). This view is based in the case of Chin Seow Noi v PP [1994] 1 SLR 135 where Yong Pung How CJ said at page 156 "The use of the single word 'includes' in our $s 3$ is clearly intended to make the definition of 'evidence' in our Evidence Act an extensive one...". Reference to this matter can also be made to other cases like Dilworth \& Ors $v$ Commissioner of Stamps [1899] AC 99; [1895-99] All ER Rep Ext 1576 and also Corporation of Portsmouth $v$ Smith \& Ors. (1883) 13 QBD 184. (Augustine Paul, 2000, pp. 16 - 17). Since the statute allow us to define the term evidence in extensive or wider way, varieties of evidence can be given in order for us to substantiate our cases. However, it should be stressed out here that any evidence submitted should be relevant as enunciated under Section 5 of the Evidence Act 1950 [Act 56] and be the best evidence to support the case (Prof. Dr. Hj. Mohd Akram Shair Mohd Akram, 1987).

When we open up the Evidence Act 1950 [Act 56], there are not so much focus being given over forensic matters in detail. The Act which consisted 167 legal provisions are divided into three parts namely, Part I which talk about relevancy, Part II which talk about proof, and Part III which talk about production and effect of evidence. If we widen our understanding over the definition and scope of forensic education, we can comfortably argues that all provisions in the Evidence Act 1950 [Act 56] relates to forensic matters. However, it would be better for us to examine the statute in detail. Among all the given provisions provided under the statute, detail aspect over forensic matters can be located easily over the authentication process of a documentary evidence. According to the Act, document means any matter expressed, described or howsoever represented, upon any substance, material, thing or article, including any matter embodied in a disc, tape, film, sound track or other device whatsoever. Document can includes letters, figures, marks, symbols, signals, signs, or other forms of expression, description, or representation whatsoever, any visual recording (whether of still or moving images), any sound recording, or any electronic magnetic, mechanical or other recording whatsoever and howsoever made, or any sounds, electronic impulses, or other data 
whatsoever, and a recording, or transmission, over a distance of any matter by any, or any combination. From the definition given, a document might include anything including piece of paper and any electronically items which can embodied materials or information's.

The method of authentication process of a documentary evidence be found under sections 61 until $90 \mathrm{C}$ of the Evidence Act 1950 [Act 56]. Section 64 of the Act states "Documents must be proved by primary evidence except in the cases hereinafter mentioned". Section 61 of the Act states that "The contents of documents may be proved either by primary or by secondary evidence". Primary evidence here means the document itself produced for the inspection of the court. Meanwhile, secondary evidence can includes certified copies given under the provisions hereinafter contained, copies made from the original by mechanical processes, which in themselves ensure the accuracy of the copy, and copies compared with such copies, copies made from or compared with the original;; counterparts of documents as against the parties who did not execute them and oral accounts of the contents of a document given by some person who has himself seen or heard it or perceived it by whatever means. The Act also stipulate the circumstances under which a documentary evidence might be given. Under Section 65 of the Act mentioned that secondary evidence may be given of the existence, condition or contents of a document admissible in evidence in the following cases namely (a) when the original is shown or appears to be in the possession or power (i) of the person against whom the document is sought to be proved, (ii) of any person out of reach of or not subject to the process of the court or (iii) of any person legally bound to produce it, and when after the notice mentioned in section 66 such person does not produce it, (b) when the existence, condition or contents of the original have been proved to be admitted in writing by the person against whom it is proved or by his representative in interest, (c) when the original has been destroyed or lost, or when the party offering evidence of its contents cannot for any other reason not arising from his own default or neglect produce it in reasonable time, (d) when the original is of such a nature as not to be easily movable, (e) when the original is a public document within the meaning of section 74 , and (f) when the original is a document of which a certified copy is permitted by this Act or by any other law in force for the time being in Malaysia to be given in evidence, and $(\mathrm{g})$ when the originals consist of numerous accounts or other documents which cannot conveniently be examined in court, and the fact to be proved is the general result of the whole collection. (Augustine Paul, 2000, pp. 539 - 633). Reference can be made on this regard to the case of Popular Industries Ltd v Eastern Garment Manufacturing Sdn Bhd [1989] 3 MLJ 360, 368, KPM Khidmat Sdn Bhd v Tey Kim Suie [1994] 2 MLJ 627, 631, and Lucas v William [1892] 2 QB 113, 116.

It is highly important for all these documentary evidence been properly examine and authenticated before it can be accepted by the court. The requirements for these evidence to be properly examined and authenticated give rise to the issue concerning forensic education itself. It is not enough for the student to understand the definition of documentary evidence without having similar understanding over the method or process over the authentication of such documentary evidence. Failure to properly authenticate such evidence can lead to many problem including making such evidence as bad piece of evidence not worthy to be given and admitted to the court. Reference can be made to several cases on this regard like the case of Alliedbank (M) Bhd v Yau Jiok Hua [1998] 6 MLJ 1, 14, Myers v Director of Public Prosecutions [1965] AC 1001, Tan Siak Heng v Rex [1950] 16 MLJ 214, Patel v Comptroller of Customes [1966] AC 356, Beh Heng Seong v PP [1972] 2 MLJ 190, and Sim Tiew Bee v PP [1973] 2 MLJ 200. Besides that, we also have forensic elements for the computer generated document enunciated under Section $90 \mathrm{~A}, 90 \mathrm{~B}$, and $90 \mathrm{C}$ of the Evidence Act 1950 [Act 56] when it touches over the aspect of document which is produced by a computer in the ordinary use of such computer as well as its authentication process. (Augustine Paul, 2000, pp. $638-$ 644). Reference can be made on this matter to the case of Gnanasegaran a/l Pararajasingam v PP [1997] 3 MLJ 1, 11. There is also forensic elements when we touch the subject matter involving expert opinion as provided under Section 45 of the Evidence Act 1950 [Act 56]. Worth to note that Section 45 of the Evidence Act 1950 [Act 56] provides the opinions of experts where its stated that "When the court has to form an opinion upon a point of foreign law or of science or art, or as to identity or genuineness of handwriting or finger impressions, the opinions upon that point of persons specially skilled in that foreign law, science or art, or in questions as to identity or genuineness of handwriting or finger impressions, are relevant facts". Interesting to note that this particular section highlight the submission of testimony from an experts in various critical areas including in the area of science and art where the number of expertise is small. (Augustine Paul, 2000, pp. 427 - 471). An expert here can include forensic scientist. Forensic scientist can come to court and testify as expert witnesses. (Further reference can be made to Shahrom Abdul Wahid, 1993, pp: 464 - 473). Reference can made on this matter to the case of Dato Mokhtar Hashim v PP [1983] 2 MLJ 232, Junaidi Bin Abdullah v PP [1993] 3 MLJ 217, and PP v Virammal AIR 1923 AIR Mad 178, and PP v Sam Hong Choy [1995] 4 MLJ 121. All these mentioned forensic matters as provided under the Evidence Act 1950 [Act 56] are being covered under the law of evidence syllabus in all law schools in the country. 


\section{FORENSIC EDUCATION EXPOSURE}

Having said about forensic matters which been discussed under Evidence Act 1950 [Act 56], we also need to realize that it is highly impossible to covered every aspect of forensic matters and in detail under the given statute or even the syllabus. Quite often, initiative need to be taken by the educator themselves to exposed their students to forensic matters in details. In Malaysia, most of the time, law schools in the country organized a simple educational trip to the Center of Analysis for Forensic Science, Department of Chemistry Malaysia, Ministry of Science, Technology and Innovation (MOSTI). There are also other places which often been consider by these law schools in order to exposed their students to the practical aspect of forensic education like hospital and police station. However the most relevant place which should be visit in order to have such exposure is the Center of Analysis for Forensic Science, Department of Chemistry Malaysia, Ministry of Science, Technology and Innovation (MOSTI). The Center of Analysis for Forensic Science, Department of Chemistry Malaysia, Ministry of Science, Technology and Innovation (MOSTI) is a nationally recognized leader in the forensic science community in the country. It provides independent and impartial forensic science services to both government agencies and to the private sector. Objectives of this center is to provide "state of the art" forensic science services to law enforcement agencies and the criminal justice community and to ensure all examinations and analyses are technically correct and this applies not only to laboratory work, but also to written reports, scene investigations and court testimonies. In the Center of Analysis for Forensic Science, Department of Chemistry Malaysia, Ministry of Science, Technology and Innovation (MOSTI), there are several divisions which can properly exposed the students to many aspect of forensic education namely, narcotics division, toxicology division, DNA forensic division, criminalistics division, and document examination division. In addition to the above matter, this center also provides other scientific support services including, expert opinions, lectures and training to law enforcement agencies, the country Attorney General's Chambers, as well as undergraduates and postgraduates of forensic science courses. (Kimia Malaysia, 2020).

\section{CONCLUSION AND RECOMMENDATION}

Though exposing students to practical aspect of forensic matters is very important to ensure students understanding over the course taken, realistically it is very difficult to cover all the forensic matters under the existing syllabus and to be taught in classes. This is due to the time limit which being provided for course taken for each semester. The only possible way for such detail forensic matters to be included under the legal curriculum is by developing a new course focusing entirely on forensic matters. However, this would be up to all law schools in the country to decide. For the time being, the best option which can be offered is by continuing to conduct educational visit to the mentioned center itself. Each law school in the country should strongly consider making such education visit a permanent activity for their student. Possible formal collaboration can and should be done between the law school and the Center of Analysis for Forensic Science, Department of Chemistry Malaysia, Ministry of Science, Technology and Innovation (MOSTI) in areas of education which can offer permanent exposure to the students over the areas of forensic education.

\section{REFERENCE LIST}

A.K. Sarkar and S.K. Awasthi. (1996). Cases and Materials on Oral and Documentary Evidence. First Malaysian Edition. New Delhi: International Law Books Services.

Augustine Paul. (2000). Evidence Practice and Procedure. Second Edition. Kuala Lumpur: Malayan Law Journal Sdn. Bhd.

Habibah Omar, Siva Barathi Marimuthu, and Mazlina Mahali. (2015). Law of Evidence in Malaysia. Second Edition. Subang Jaya: Thompson Reuters Asia Sdn. Bhd.

Hamid Ibrahim and Maimoonah Hamid. (1993). Law of Evidence. Kuala Lumpur: Central Law Book Corporation Sdn. Bhd.

Hamid Sultan Abu Backer. The Law of Evidence. Fourth Edition. Kuala Lumpur: Janab (M). Sdn. Bhd.

Job Description for Forensic Laboratory Scientists. Crime Scene Investigator EDU. (2020). http://www.crimesceneinvestigatoredu.org/forensic-scientist-job-description/.Retrieved on September 2, 2020.

Kasinathan Nadesan. (2007). Forensic Medicine and Science for Malaysian Lawyers. Kelana Jaya: Malayan 
Law Journal Sdn Bhd.

Kimia Malaysia. (2020). https://www.kimia.gov.my/en/center-of-analysis-for-forensic-science/. Retrieved on September 3, 2020.

M.R. Zafer. (1994). Law of Evidence in Malaysia: An Outline. Kuala Lumpur: International Law Book Services.

Mariette Peters. (2013). Law of Evidence in Malaysia. Petaling Jaya (Selangor Darul Ehsan): Lexis Nexis.

Prof. Dr. Hj. Mohd Akram Shair Mohd Akram. The best evidence rule. [1987] 1 Current Law Journal (CLJ).

Shahrom Abdul Wahid. (1993). Patologi Forensik. Kuala Lumpur: Dewan Bahasa dan Pustaka (DBP). 